\title{
INTEGRATION OF THE PACKAGING WASTE UTILIZATION SYSTEMS OF FINLAND AND RUSSIAN NEIGHBORING AREAS
}

\author{
Hannariina Honkanen \\ Mika Horttanainen \\ Risto Soukka \\ Lappeenranta University of Technology, Finland
}

\begin{abstract}
This study examines the situation of energy recovery of packaging waste in Finland, packaging waste utilization in the Russian neighboring areas and the state of operational and business environment of packaging waste recovery development schemes. Waste management and recovery of waste materials carry current and focal problems in Finland and in Russia. Both tightening national environmental legislation under the influence of $\mathrm{EU}$ regulations and the need to reclaim wastes have caused the state of change in the waste management field in Finland. In Russia, the situation of reclaiming waste materials is poorer and the recovery rates of waste fractions are low.
\end{abstract}

Finnish energy production facilities seem to have obvious needs for replacing fossil fuels with renewable energy sources and waste derived fuels given that the quality requirements exist. The situation with exceeding the demand and companies competing for waste derived fuels is already foreseeable. In the sparsely populated country, the collecting of waste for recovery is also a matter of feasibility. On the other hand, economic growth, the growing purchasing power and the supply of consumer goods in Russia, especially in the city of St. Petersburg and Leningrad region close to the Finnish border, have a measurable effect on the volume and composition of generated packaging waste, now mainly disposed in landfills.

The cooperative Finnish-Russian cross-border recovery of packaging waste is a potential option for Finnish and Russian companies to develop their businesses and promote waste recovery. The biggest challenges in implementing new operations relate to legislative differences, foreign license practices and different waste management systems. In this paper, we present a theoretical model of an energy recovery scheme from the perspective of Finnish energy production facility.

\section{KEYWORDS}

Packaging waste; Waste utilization; Energy recovery; Transfrontier shipment.

\section{INTRODUCTION}

Packaging waste is generated as a consequence of operations in communities, house building, industry and agriculture. Packaging waste, as other waste, has to be treated to avoid any hazard to human health and the environment. Waste management systems are outlined to 
conform to the environmental, economic and social requirements in given regions. Conservation and legislative steering have created a global need to reduce greenhouse gas emissions in waste management and to reduce the disposal of waste in landfills, promoting the development of efficient treatment technologies and reclamation of waste as material or as energy.

The European Union and Finland have set their aspiring objectives at increasing waste recovery. The European landfill directive (1999) and Packaging waste directive (1994) aim at reducing the amount of biodegradable municipal waste ending up in landfills. Thus, the number of landfills has decreased and disposal costs have risen in Finland. Longer distances between the source of the produced waste and the landfill involve higher transportations costs. In general, the recovery of waste fractions arising from industrial processes and sourceseparated waste fractions from municipalities is working in Finland, but in any case, the utilization of waste materials has to be economically feasible. In the reclamation of mixed waste streams, a suitable option is seen to be their co-incineration in industrial energy production boilers. Among others, [1] have discussed about the waste hierarchy and the priority of recycling over incineration with energy recovery in principle. In Finland, the national goals set for the increased recovery of biodegradable waste generated in municipalities can, in practice, be reached only through an increased energy-oriented recovery of waste.

In Russia, the situation of reclaiming waste materials is poorer than in Finland and the recovery rates of waste fractions are low. This also applies to the growing of packaging waste volumes as a result of economic growth. In the areas of the city of St. Petersburg and in the Leningrad region, waste is often disposed and dumped into the environment without any appropriate treatment, which causes environmental and health problems. Because of the prevailing systems and inadequate financing, the development of waste management is difficult. However, in the Russian context, the city of St. Petersburg is seen as a forerunner in the development of a more sustainable waste management strategy.

In this paper, some of the results of the EU project "Material Exchange"l are used. The premise of the project was to explore the industrial, commercial and municipal wastes and possibilities to reclaim waste materials with combining the by-product markets in Southeast Finland and in the Russian neighboring areas.

As a basis for discussion, the integration of waste material streams from both sides of the Finnish-Russian border is assumed to be a vital possibility for finding new solutions for the challenges of waste recovery. Larger volumes of materials increase the cost-efficiency of recovery processes of by-products and waste materials, and thus the implementation of necessary investments becomes easier. The selection of packaging waste for closer examination is mainly due to interest in utilizing the valuable plastic fraction of waste streams ending up in landfills and the existing need for high-quality material for recovered fuel production for the Finnish industry. The main challenge of integrating the waste recovery systems seem to do with the issues relating to transporting waste materials across the border between Russia and Finland, which also constitutes the border between Russia and the EU.

\footnotetext{
${ }^{1}$ Project Exchange of secondary raw materials and technology between Northwest Russia and Southeast Finland - Material Exchange (11/2005-12/2007) was funded mainly by the EU and Southeast Finland Regional Environmental Centre and coordinated by the Lappeenranta University of Technology.
} 

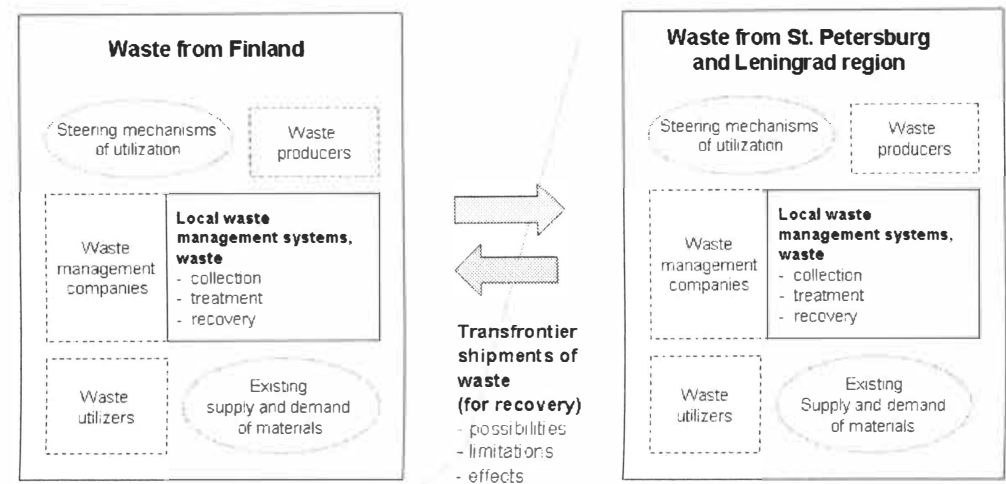

Figure 1. Operating and business environment of waste recovery systems in Finland and in the Russian neighboring areas [8].

Finland has strong traditions and viable systems in the reuse of packaging, and the use, reuse and recovery of packaging is supervised and organized by producer organizations and The Environmental Register of Packaging PYR. However, waste management systems and local practices on sorting have varied greatly between municipalities. The EU waste incineration directive coming into force has restrained and temporarily depressed the development of an efficient energy recovery of packaging waste in energy production facilities.

Packaging waste consists mainly of plastic, paper, cardboard, wood, glass and metal waste materials. Plastic waste recovery has an increasingly important status among packaging waste materials. Both in Finland and in Russia, only limited amounts of used plastic packaging material is recovered. The Finnish challenges of plastic material recovery focus on mixed plastic waste streams due to inexistent sorting systems and overall small material flows.

The objective of this paper is to present results of studies related to the basis and possibilities of a more efficient recovery of packaging waste with mutual Finnish-Russian cross-border schemes, including transfrontier shipments, under present waste management system circumstances as well as prevailing challenges and limitations of operations (see Figure l). Also a theoretical model of Finland-based energy recovery of packaging waste collected from the city of St. Petersburg is presented.

\section{PACKAGING WASTE VOLUMES AND RECOVERY IN TARGET AREAS}

\subsection{General about packaging use and packaging waste}

Almost every commercial product is distributed or sold in some kind of a packaging. Packaging waste is a notable and growing waste stream [6]. From the environmental perspective, recoverability is an important property of packaging. It is also a precondition for reaching the recovery targets set by the EU directives and national schemes. 
Table 1. Packaging materials and their characteristics from the recovery perspective. (Gathered from sources [2, 9]).

\begin{tabular}{|c|c|}
\hline $\begin{array}{l}\text { Wood-based } \\
\text { packaging } \\
\text { (paper, } \\
\text { paperboard, } \\
\text { cardboard, } \\
\text { wood and cork) }\end{array}$ & $\begin{array}{l}\text { - PAPER - versatile and low cost, accounts for the largest share of materials used in } \\
\text { packaging } \\
\text { PAPERBOARD - includes a variety of packaging for different purposes (often coated, e.g. } \\
\text { plastic or aluminum foil) } \\
\text { - CARDBOARD - the most common in container material (e.g. slotted containers) } \\
\text { - } \quad \text { WOOD PACKAGING - used mainly as versatile, reusable and repairable pallets } \\
\text { Lower heating value: from } 12,7 \mathrm{MJ} / \mathrm{kg} \text { (cardboard boxes) to } 27,2 \mathrm{MJ} / \mathrm{kg} \text { (waxed board) }\end{array}$ \\
\hline Plastic & 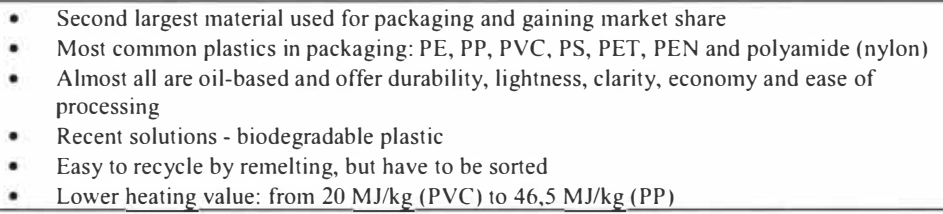 \\
\hline
\end{tabular}

This study is concentrated on packaging wastes, which have a potential both in view of material and energy recovery. Thus packages made out of non-combustible materials, such as glass and metal, are excluded from this study. Table $I$ presents the main combustible materials constituting the packaging waste streams. These materials are characterized by high recoverability.

Moreover, because the emphasis of the examination is on energy recovery of packaging waste, the role of plastic packaging should be highlighted. In material recovery, sorted plastic waste is considered as an increasingly valuable material to replace virgin raw materials. For example, the price of commodity plastics has followed the crude oil price quite closely during the past decade [4]. On average, both prices have shown continuous increase in spite of the fact that the price of oil experienced a slight decline at the end of 2006. As concerns mixed plastic waste or plastic waste mingled with other fractions, energy recovery is the most suitable utilization option (see Figure 2). Plastic carries a high calorific value, so it improves the energy content of recovered fuels over many other combustible waste materials. The global main concern relating to the handling of plastic waste is to promote its separation from landfills, not the least because of its natural character of ineffective decomposition. 


\begin{tabular}{|c|c|c|c|c|}
\hline \multirow{5}{*}{$\begin{array}{r}\text { Costs increase } \\
\text { as more } \\
\text { collection and } \\
\text { separation is } \\
\text { required for the } \\
\text { recovery process }\end{array}$} & & $\begin{array}{l}\text { MECHANICAL } \\
\text { RECYCLING }\end{array}$ & $\begin{array}{l}\text { CHEMICAL } \\
\text { RECYCLING }\end{array}$ & $\begin{array}{l}\text { ENERGY } \\
\text { RECOVERY }\end{array}$ \\
\hline & $\begin{array}{l}\text { Sorted, single } \\
\text { type plastic } \\
\text { waste }\end{array}$ & Preferred option & Realistic option & Realistic option \\
\hline & $\begin{array}{l}\text { Mixed plastics } \\
\text { waste }\end{array}$ & Realistic option & Realistic option & $\begin{array}{c}\text { Preferred option } \\
\text { (Solid recovered fucl) }\end{array}$ \\
\hline & $\begin{array}{l}\text { Mixed plastics } \\
\text { waste }+ \text { paper } \\
\text { etc. }\end{array}$ & 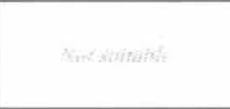 & Evil surtatis & $\begin{array}{l}\text { Realistic option I } \\
\text { (Solid recovered fuel) }\end{array}$ \\
\hline & $\begin{array}{l}\text { Mixed plastics } \\
\text { waste }+ \text { paper } \\
\text { etc. }\end{array}$ & Nits wentith & 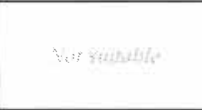 & $\begin{array}{l}\text { Realistic option II } \\
\text { (Municipal solid waste } \\
\text { combustion) }\end{array}$ \\
\hline
\end{tabular}

Figure 2. Plastic waste applicability for recycling and recovery processes [3].

\subsection{Packaging waste volumes and recovery in Finland}

In addition to international and national legislation and waste policies, waste reclamation is steered by Finland's national and regional waste schemes. Moreover, the waste tax is one of the major practical controlling factors in the waste management field, even if the steering is considered effective enough with current rate of taxation. From the business point of view, waste recovery is steered not only by markets but also by company image motives.

In 2005, the amount of reused packaging exceeded 2.3 million tons in Finland (see Table 2) $[5] .^{2}$ According to the EEA statistics, generated amount of packaging waste is less than 100 $\mathrm{kg}$ per capita in Finland, very low by European standards [6]. ${ }^{3}$ The reuse of packaging is most consistent in metal packaging, covering $90 \%$ of all metal packaging, but also large shares of wood, glass and plastic packaging are used more than once. Only the reuse of fiber packaging is still minor, the rate being about $3 \%$. As regards the recovery of packaging exiting from use, greatest losses are within plastic and fiber packaging. Losses ranged from 5\% of metal and wood packaging to $2 \%$ of plastic. [5]

A current change in the recycling of plastic packages in Finland is the new PET bottle recycling system. This change is due to a reform of packaging taxation entering into force in 2008 , with the objective of favoring the use of recyclable plastic bottles parallel to refillable bottles.

\footnotetext{
${ }^{2}$ According to PYR, these statistics cover over $93 \%$ of the packaging supplied to markets.

${ }^{3}$ According to the EEA, national figures may not be directly comparable because of inconsistencies of approach.
} 
Kalmar ECO-TECH '07

KALMAR, SWEDEN, November 26-28, 2007

Table 2. Use, reuse and recovery of packaging in Finland, 2001-2005 (gathered from [5]).

\begin{tabular}{|c|c|c|c|c|c|c|c|c|c|c|c|c|}
\hline \multicolumn{13}{|c|}{ REUSE OF PACKAGING } \\
\hline Year & \multicolumn{2}{|c|}{ Total } & \multicolumn{2}{|c|}{ Fiber } & \multicolumn{2}{|c|}{ Glass } & \multicolumn{2}{|c|}{ Metals } & \multicolumn{2}{|c|}{ Plastic } & \multicolumn{2}{|c|}{ Wood } \\
\hline 2001 & \multicolumn{2}{|l|}{$62 \%$} & \multicolumn{2}{|l|}{$3 \%$} & \multicolumn{2}{|l|}{$81 \%$} & \multicolumn{2}{|c|}{$88 \%$} & \multicolumn{2}{|c|}{$69 \%$} & \multicolumn{2}{|c|}{-} \\
\hline 2002 & \multicolumn{2}{|l|}{$66 \%$} & \multicolumn{2}{|l|}{$3 \%$} & \multicolumn{2}{|l|}{$80 \%$} & \multicolumn{2}{|l|}{$91 \%$} & \multicolumn{2}{|l|}{$71 \%$} & \multicolumn{2}{|l|}{ - } \\
\hline 2003 & \multicolumn{2}{|l|}{$71 \%$} & \multicolumn{2}{|l|}{$3 \%$} & \multicolumn{2}{|l|}{$80 \%$} & \multicolumn{2}{|l|}{$90 \%$} & \multicolumn{2}{|l|}{$71 \%$} & \multicolumn{2}{|l|}{$81 \%$} \\
\hline 2004 & \multicolumn{2}{|l|}{$71 \%$} & \multicolumn{2}{|l|}{$3 \%$} & \multicolumn{2}{|l|}{$78 \%$} & \multicolumn{2}{|l|}{$90 \%$} & \multicolumn{2}{|l|}{$73 \%$} & \multicolumn{2}{|l|}{$78 \%$} \\
\hline 2005 & \multicolumn{2}{|l|}{$71 \%$} & \multicolumn{2}{|l|}{$3 \%$} & $74 \%$ & & $90 \%$ & & $72 \%$ & & $78 \%$ & \\
\hline $\begin{array}{l}\text { Total use in } \\
2005, t\end{array}$ & 23341 & & 25630 & & 32470 & & 44966 & & 3549 & & 9486 & \\
\hline $\begin{array}{l}\text { Reuse in } \\
2005, \mathrm{t}\end{array}$ & 16521 & & 8700 & & 24080 & & 4049 & & 2548 & & 7429 & \\
\hline RECOVE & $\mathrm{RYOH}$ & $\mathrm{PACK}$ & $\mathrm{AGIN}$ & & & & & & & & & \\
\hline & Total & & Fiber & & Glass & & Meta & & Plast & & Woc & \\
\hline Year & REC & $\begin{array}{l}\text { REC + } \\
\text { ENE }\end{array}$ & REC & $\begin{array}{l}\text { REC + } \\
\text { ENE }\end{array}$ & REC & $\begin{array}{l}\text { REC + } \\
\text { ENE }\end{array}$ & REC & $\begin{array}{l}\text { REC + } \\
\text { ENE }\end{array}$ & REC & $\begin{array}{l}\text { REC + } \\
\text { ENE }\end{array}$ & REC & $\begin{array}{l}\text { REC + } \\
\text { ENE }\end{array}$ \\
\hline 2001 & $47 \%$ & $62 \%$ & $58 \%$ & $74 \%$ & $50 \%$ & $50 \%$ & $39 \%$ & $39 \%$ & $15 \%$ & $44 \%$ & - & - \\
\hline 2002 & $49 \%$ & $61 \%$ & $61 \%$ & $75 \%$ & $50 \%$ & $50 \%$ & $46 \%$ & $46 \%$ & $15 \%$ & $38 \%$ & - & - \\
\hline 2003 & $41 \%$ & $67 \%$ & $63 \%$ & $72 \%$ & $61 \%$ & $61 \%$ & $50 \%$ & $50 \%$ & $14 \%$ & $37 \%$ & $7 \%$ & $84 \%$ \\
\hline 2004 & $40 \%$ & $68 \%$ & $70 \%$ & $77 \%$ & $55 \%$ & $58 \%$ & $55 \%$ & $55 \%$ & $15 \%$ & $34 \%$ & $7 \%$ & $78 \%$ \\
\hline 2005 & $43 \%$ & $68 \%$ & $79 \%$ & $88 \%$ & $63 \%$ & $65 \%$ & $54 \%$ & $54 \%$ & $14 \%$ & $15 \%$ & $5 \%$ & $76 \%$ \\
\hline $\begin{array}{l}\text { Packaging } \\
\text { waste, total } \\
\text { in } 2005, \mathrm{t}\end{array}$ & 68880 & & 24770 & & 83900 & & 44700 & & 10010 & & 2056 & \\
\hline $\begin{array}{l}E U, \text { goal } \\
2008\end{array}$ & $\begin{array}{l}55 \\
80 \%\end{array}$ & $60 \%$ & $60 \%$ & & $60 \%$ & & $50 \%$ & & $22,5^{\circ}$ & & $15 \%$ & \\
\hline $\begin{array}{l}\text { Finland, } \\
\text { goal } 2008\end{array}$ & $\begin{array}{l}55- \\
80 \%\end{array}$ & $61 \%$ & $60 \%$ & $75 \%$ & $60 \%$ & & $50 \%$ & & $22,5^{\circ}$ & & $15 \%$ & \\
\hline
\end{tabular}

i* REC = recycling, ENE = energy recovery

(** Includes also "other packaging", which totaled $6800 \mathrm{t}$. The assumption was that this fraction was not recovered.

At present we have not yet clear statistical data about the impacts of the recent EU Waste incineration directive on the recovery rates of packaging waste. Since the co-incineration of recovered fuels has significantly decreased in power plants, the recovery rates of fiber, plastic and wood packaging has supposedly been falling in 2006. In fact, the decrease is already seen in recovery figures of plastic for the year 2005. To reach the national recovery goals set until the year 2008, there is an imminent need for actions promoting recycling of plastic and wood packaging. Other recovery goals, apart from the total recycling of packaging waste, have already been reached in Finland. However, a notable rate of reuse of packaging should be seen in EU to favor the system as nature of preventing generation of waste.

During the past few years, sourceseparated energy waste fraction has been collected from some of the Finnish municipalities. Despite the fact that legislative steering mechanisms have temporarily restrained energy recovery of waste otherwise ending up in landfills, there are several ongoing energy production projects related to the recovery of waste in Finland, with some already implemented. The interest in waste fractions suitable for raw materials of highquality recovered fuel is increasing in the near future.

\subsection{Packaging waste volumes and recovery in the city of St. Petersburg and in the Leningrad region}

In Russia, environmental issues started to attract attention in the 1990s, illustrating the fact that the concept of transition to sustainable development starts to be recognized by the 
governmental authorities of the Federation, among others. Major problems related to municipal and industrial waste have been identified, particularly in the big cities of Russia, where industrial and commercial activity and population are clearly concentrated. The rate of municipal waste increase, consumption and thus, for example, the use of novel packaging, electric and electrical appliances and cars is increasing. [8]

The city of St. Petersburg, the second biggest city of Russia, has a population of 4.7 million people and the population density is about 3,200 per one square kilometer.e A large number of industrial enterprises and energy production facilities operate in the territory of the city. The population of the Leningrad region is about 1.7 million people. The industry in the region is focused on internationally important sectors such as the non-ferrous metals, mass and paper, chemical, engineering and building materials industries. One of the most focal environmental problems of these regions is related to the treatment of municipal and industrial waste and the shortages in the management system. [8]

Due to the absence of packaging waste statistics from the Russian target areas, the volumes are mostly estimates based on the generated amounts of municipal waste. Owing to the high density of waste generation and big volumes of waste, we choose to present estimates of the generated packaging waste amounts and recovery situation the city of St. Petersburg.

According to the St. Petersburg statistics, about 1.54 million tons of municipal waste was generated in 2005. Households accounted for over $80 \%$ of this waste. The amount of household waste is estimated to increase up to 1.77 million tons by the year 2010, to 1.9 million tons by 2015 and 2.24 million tons by 2025. [7] Paper and cardboard account for about $20 \%$ of municipal waste, plastics $12 \%$, glass $10 \%$, ferrous and non-ferrous metals $5 \%$ and wood 4\%. [8] A major share of these fractions comes, mostly likely, from packaging.

According to the latest estimates, $22.5 \%$, or 1.73 million mé , of municipal waste was steered to mechanical treatment by the two city owned treatment facilities in 2005 . The rest of the waste is landfilled. [7] According to estimates of the average composition of the mechanically treated waste stream, waste paper accounts for $21 \%$, metals $3 \%$, broken glass $2 \%$, PET plastic $3 \%$, other plastic $6 \%$, bulky waste $2 \%$ and others $63 \%$. Of the different fractions of waste coming from municipalities, $10 \%$ of the total waste amount or 150,000 tons are separated for recovery. [8]

New waste handling facilities and landfills are being built and there are plans to renew the old ones to meet the increasing waste volumes in St. Petersburg. The principal objectives concerning improving municipal waste management systems still seem to focus on more efficient collection and management of hazardous wastes. However, the long-term recovery rate target of municipal waste in St. Petersburg is $35 \%$ in 2025. Shares of packaging made of paper and cardboard including plastic and foil are estimated to increase rapidly whereas the share of clean paper and cardboard waste is going to decrease. A significant relative increase is also predicted in all plastic waste, whereas the amounts of glass and ferrous metals are going to decrease to some extent. [8]

We have studied the availability of the combustible packaging waste fraction from the Russian target areas. One of the findings is that there is no source separation system to assort combustible and non-combustible waste in target areas, and it is difficult to evaluate this type of information. Big hypeemarkets produce large amount of very clean packaging waste, such

\footnotetext{
${ }^{4}$ In comparison, Finland has about 5.3 million inhabitants.
} 
as cardboard, polyethylene and wood pallets. Large factories also produce significant amounts of packaging waste, mainly wood-based. [8]

\section{POSSIBILITIES TO INTEGRATE PACKAGING WASTE SYSTEMS}

With conception integration, we refer to new concrete and individual cross-border recovery initiatives and business operations. In Figure 3, possible options for packaging waste management and recovery are presented. The main options include packaging waste landfill disposal and domestic or foreign recovery for material or energy use.

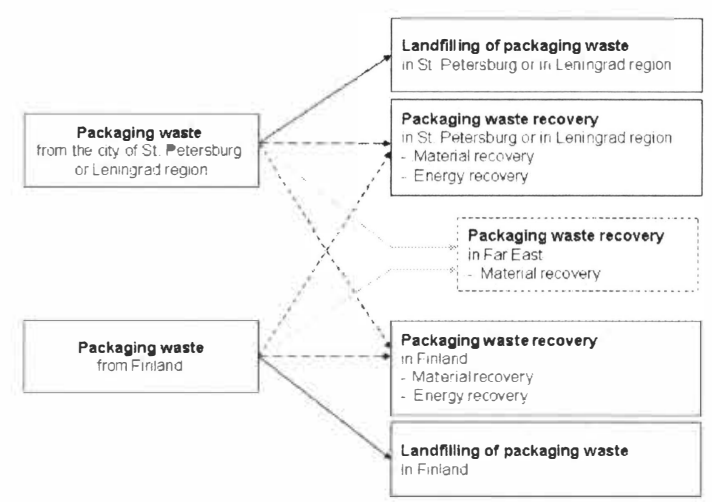

Figure 3. Packaging waste from Finland and Russian target areas - theoretical disposal or optional recovery routes.

The lack of demand for recycled plastics has been an obstacle to the development of collection systems while the lack of supply prevents the development of recovery processes, at least in Finland. One solution is to transport the material further to where the actual demand is, e.g. to the Far East. In Finnish plastic recycling ventures, this has been discovered to be a feasible operation [10].

Despite the fact that waste recovery should be promoted on each side of the Finnish-Russian border and the distribution of possible benefits should be equally considered, the following chapters focus on the challenges and possibilities mostly from the Finnish point of view.

\subsection{Limitations of cooperative waste utilization systems}

Finland and Russia have different legislative bases and steering mechanisms for waste management and waste recovery. Experiences of trade and transfrontier shipments of waste materials between Finland and Russia have mainly centered on a limited number of international players. 
The challenges of Finnish-Russian cross-border packaging recovery actions from the Finnish point of view are summarized in the following:

- Legislation - undeveloped in waste management and recovery, differences with the EU regulations [in $\mathrm{Ru}$ ];

- Vagueness and case-specific definition of waste and other grading differences [in Fin/Ru];

- Foreign license practices and bureaucracy [in $\mathrm{Ru}$;

- Possible difficulties and delays due to border crossing [in Fin/Ru];

- Differences in waste management systems - lack of source-separation systems, lack of monitoring systems, large and variable group of companies, ownership of waste [in Ru];

- Underground economy in waste recovery business [in $\mathrm{Ru}$ ];

- Low price of landfilling - lowers local interest in source-separation and recovery business [in $\mathrm{Ru}$;

- Continuance of operations, e.g. reliability of fluency of material deliveries [in Ru];

- Cultural differences in business [in Fin/Ru];

- Uncertainties in material origin vse quality demands [in Ru]e

\subsection{Incentives and advantages of cooperative waste utilization systems}

Distances between the Southern Finland and neighboring regions in Russia are relatively short and there is a distinct need to explore new ways to promote mutual problem-solving with waste management and recovery across the bordere One of the major considerations is the fact that the generated waste volumes and the demand for recyclable waste materials differ in Finland and in Russia. This supports the possibility of exchange and trading of waste matereals and waste-derived products between the Finnish and Russian companiese

The potentials of the Finnish-Russian cross-border packaging recovery actions from the Finnish point of view are summarized in the following:

- Large potential of unutilized waste and by-products [in Ru];

- Demand for recoverable materials, e.g. combustible waste for energy recovery [in Fin];

- Opportunity to increase material streams to create feasible processes [in Fin/Ru];

- Decrease of environmental load [in Fin/Ru];

- Increased replacing of virgin materials with waste materials, saving natural resources [in Fin/Ru];

- Improvement of company image (corporate responsibility, trendsetters) [in Fin/Ru];

- Economic benefits (recovery rates, additional income from waste, new projects and business, lower investments per ton of recovered waste) [in Fin/Ru].

\section{RESULTS AND DISCUSSION}

We have discovered that Finnish companies have several types of demand for recycling materials, including quality paper, non-ferrous metals, wood waste and packaging derived fuel. Furthermore, Finnish municipalities and industries generate many types of unutilized waste which could constitute valuable raw material for businesses and processes outside Finland, e.g. in Russia.

We created a model of energy recovery of packaging waste collected from the city of St. Petersburg and transported to Finland (see Figure 4). The idea is to examine environmental effects of changing the fuel distribution in energy supply system of a specefic factorye The 
selected recovery target is mainly based on the actual demand existing in the Finnish business sector. With the cross-border material recovery scenario options, we faced some questions related to the uncertainties of material origin and quality demands. However, the material recovery scenarios preferred by the prevailing waste strategies as well as the energy recovery option on the Russian side of the border should also be examined in further research.

The further research is going to focus on economic and environmental impact analyses of the selected models. Material-specific environmental effect analyses are going to be made for packaging waste fractions. From the business development point of view, essential outcomes would include economic calculations of the generated models. However, environmental impacts should be the basis for evaluating the most suitable option for recovery of packaging waste. The results of these analyses, as well as the effective financial and administrative steering mechanisms, should direct the choice of the feasible operations.

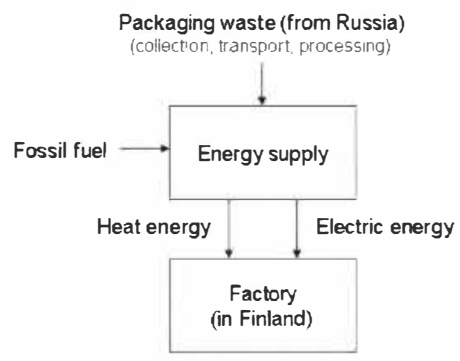

Figure 4. Energy recovery scheme from the factory perspective.

\section{CONCLUSIONS}

In this paper, packaging waste generation and prevailing recovery systems have been reviewed in the geographical areas under consideration. Statistical data from the Finnish side of the border is more accurate and it has been more easily available. As a consequence of a missing monitoring system of packaging waste, most of the results from the Russian side are estimates and are based on the information about municipal waste.

The inexistent source-separation system of Russian waste streams makes many recovery schemes difficult because of the possible prevailing preconditions of waste materials quality. This can also be a matter of profitability. The city of St. Petersburg generates extremely large waste volumes, landfilled to a great extent.

We have concluded that the cooperative Finnish-Russian cross-border recovery of packaging waste is a potential option for Finnish and Russian companies to develop their businesses and promote waste recovery. The biggest challenges in implementing new operations relate to legislative differences, foreign license practices and different waste management systems. However, experiences of several Finnish companies indicate that these challenges are beatable. Financial considerations are the most essential aspects when making decisions about concrete business actions. However, environmental considerations are associated with their own incentives. 
Designed from the perspective of a Finnish plant, we presented a simple model of energy recovery of Russian packaging waste in Finland. The analysis of the economic and environmental effects of this and other previously presented packaging waste recovery options should be continued in further studies.

\section{ACKNOWLEDGEMENTS}

Financial and other support for this study has been provided by Southeast Finland - Russia Neighborhood Program, The Kouvola Region Federation of Municipalities, Cursor Ltd, Stora Enso Plc, Hyötyvisio Ltd, Lahti Science and Business Park Ltd and Etelä-Karjalan jätehuolto Ltd, which are gratefully acknowledged.

\section{REFERENCES}

[1] Finnveden, G., Johansson, J., Lind, P., Moberg, A., 2005. Life cycle assessment of energy from solid waste - part 1: general methodology and results. Journal of Cleaner Production 13 (2005), 213-229.

[2] Aarnio, T., 2006. Challenges in packaging waste management: A case study in the fast food industry. Lappeenranta University of Technology. Diss.

[3] PlasticsEurope. 2006. Waste management Association of Plastics Manufacturers. [retrieved Sep 21, 2006]. From: http://www.plasticseurope.org/content/default.asp?PageID=94

[4] Muoviteollisuus ry. 2007. Tiedotteet - Muoviteollisuus tiedottaa 26.4.2007 [retrieved Sep 17, 2007] From: http://www.muoviteollisuus.fi/tiedotteet.htm [in Finnish]

[5] PYR Oy. 2007. Recovery statistics. The Environmental register of packaging PYR Ltd. [retrieved Sep 17, 2007] From: http://www.pyr.fi/hyoty_6_1.htm

[6] European Environment Agency, 2005. Effectiveness of packaging waste management systems in selected countries: an EEA pilot study. EEA Report No 3/2005.

[7] St. Petersburg Administration. 2006. ЭКОЛОГИЧЕСКАЯ ПОЛИТИКА САНКТПЕТЕРБУРГА НА ПЕРИОД с 2008 по 2012 годЫ (pdf document). [retrieved Sep 17, 2007] From: http://www.gov.spb.ru/Document/1161591757.pdf

[8] Honkanen, H., Värri, H., Soukka, R., Horttanainen, M., 2007. Material Exchange project, final report. Lappeenranta University of Technology. [in Finnish] [unaccomplished 28 Sep 2007]

[9] Alakangas, E., 2000. Suomessa käytettyjen polttoaineiden ominaisuuksia [Properties of fuels used in Finland]. Technical Research Centre of Finland. VTT Research Notes 2045.

[10] Horttanainen, M., Friari, P., Honkanen, H., Luoranen, M., Marttila, M., 2007. Recycling of the plastic waste of farms - effects of high oil price and changes in waste management. Lappeenranta University of Technology. ISWA conrefence pape 